\title{
AUDIENCE CONCERN OF ECO-FASHION BY FASHION REVOLUTION INDONESIA THROUGH MARKETING COMMUNICATION IN JAKARTA
}

\author{
Kevin Tan \\ Marketing Communication, London School of Public Relation Jakarta \\ tankevyn@gmail.com
}

\begin{abstract}
After Rana Plaza tragedy, Fashion Revolution has came to Indonesia on 2016, deliver the objective is to unite people work together to change the perspective about the clothes are sourced, produced and consumed. However, based on Fashion Revolution Indonesia statement, it is challenging to evoke consumer's concern about eco-fashion.

The concern problem of sustainable fashion remains until now. Simply, the consumers don't care, trying to deny, blaming others and refuse to take responsibility. Fashion Revolution Indonesia needs to figure out another way to communicate with audience who originally doesn't concern about eco-fashion in the first place. The goal of this research is to analyze Fashion Revolution Indonesia marketing communication implementation towards audience concern about ecofashion.

Using qualitative approach, which the researcher gathers the data. Social marketing is more difficult rather than commercial marketing, which prestige, exclusivity, design options, quality, and pricing are some of the commercial marketing elements cater what consumer likes. In the other hand, social marketing is focused on making attitude change for social cause and give up the addictive behavior.

By conclusion, Fashion Revolution Indonesia must understand how the ecosystem works to do the marketing communication in social context from internal and external, because social change is a complex issue. From the way they communicate, the message, media to promote, the organization, campaigners and partners themselves, every single one of the elements are important to lead an impact of attitude change to the audience.
\end{abstract}

Keywords: Eco-Fashion, Fast Fashion, Concern, Marketing Communication, Fashion Revolution 


\section{INTRODUCTION}

Sustainable fashion or also known as eco-fashion is a concept of making garments in sustainable ways to maximize the positive and reduce the negative impacts for environment, social, economic (Moon, Youn, Chang \& Yeung, 2013, pp. 392 - 401). For the eco-fashion materials, according to the Made By Organization (2013), mechanically recycled nylon, mechanical recycled polyester, organic flax, organic hemp, recycled cotton and recycled wool are the fabrics, which have the lowest environmental impact (p. 6).

The benefit of sustainable fashion, the system can be divided into 3 aspects: planet, people \& profit. For the consumers, eco-fashion can create a safe environment with fewer chemicals in production. It's also increase product satisfaction, because of better quality, long lasting products, promote well-being and happiness from materialistic consumption. Socially, it creates better working conditions for textile workers by increasing the end price of the products. For the environment, it creates less production waste, cleaner process for slower cycles. If we see from the business perspective, it is new opportunity to make profit through service approach and encourage less materialistic industrial manufacturing (Niinimaki, 2013, p. 35).

Eco-fashion was existed because of mass fashion consumption effect of fast fashion industry. Fast fashion comes when the consumer's demand for the latest trend pushes the suppliers for the shorter lead times and constant regeneration of fashion items for weekly or daily at times (Tokalti \& Kizilgun, 2008, pp. 146-162).

Zara, H\&M, TopShop and Primark are the industry leaders of fast fashion, which they were focused on affordable trendy clothing around 1990s or 2000s (Idacavage, 2016, June 8). Fast fashion made consumers to meet their desires for pleasure, new experiences, status and identity through impulsively buying clothes. Seeking to wear something new every week (Bianchi \& Birtwistle, 2011). Fast fashion is not only just low-end customer, but loyal high-end customers started to mix luxury fashion with fast fashion. Many wealthy consumers are becoming loyal with fast fashion as well (Rohwedder, 2004, February 24).

The first initial introduction of eco-fashion came from brands such as Patagonia and Esprit. They were trendsetters to use organic cotton in the early nineties. Esprit showcased their E-Collection in 1991 and Patagonia used organic cotton in 1996 (Henninger, Alevizou, Goworek \& Ryding, 2017).

Kate Fletcher stated that slow fashion is about designing, producing, consuming and living better. It's quality based and not time-based. Fast fashion isn't about speed, but it's greed to sell more and make more money. Labour, capital and natural resources got 
juggled and squeezed to get maximum profits. Short lead times and cheap clothes are made possible by labour and natural resources exploitation (Fletcher, 2007, June 1)

Despite of this, fast fashion tend to fade out easily after the couple of seasons, low quality \& low pricing of fast fashion products encourage people to buy multiple clothes at once. After that, they will dispose of the clothes shortly thereafter, resulting in increasing fashion waste (Fletcher, 2010, pp. 259 - 266). Using promotions like celebrity seeding, glossy magazines, social media, haul videos to amplify "must have" motivation to consumers until becomes an addiction. The fashion giants saw this enormous potential of these self-promotions for their advertising purposes (MK\&G, 2017, p. 14-15).

The moment of people were afraid of happened. A catastrophic incident had occurred in Bangladesh. On April 24, 2013, Rana Plaza, eight story commercial building for garment factories in Savar, Bangladesh (Yardley, 2013, May 22), which major fast fashion brands including Primark, Matalon, Mango and Benetton (Smithers, 2013, April 29) collapsed leaving 1.127 dead and about 2.500 were injured (Rubya, 2014, pp. 685 - 718). It was the deadliest incident in garment industry history (Motlagh, 2016, September 7). The rana plaza was built illegally after initial construction by added three additional floors (World Health Organization, n.d.). Since then, it cames a programme of random audits through global supply chain, ensuring that fashion suppliers comply with long-standing social, labor and environmental standards (Smithers, 2013, April 29).

Fashion Revolution is a non-profit global movement, which comes from UK and established in 2013, to response Rana Plaza disaster in Bangladesh. Fashion Revolution's mission is to bring everyone across the value chain, including farmer to consumer, raise awareness of the fashion industry's most pressing issues, advocate positive change and celebrate those who are creating more ethical and sustainable future for fashion (Fashion Revolution, n.d). Fashion Revolution also came to Indonesia. Started on 2016, April 24th. The first event was conducted at Senayan City, Fashion Nation event.

In November, 11 ${ }^{\text {th }}$ 2017, the researcher has come to Fashion Revolution event, which it was a talk show event, collaborated with Pasar Semesta, which brought the topic about Sustainable Fashion talk. This event, the speakers were giving the education about the behind the scene of fast fashion and introduction of sustainable fashion. One of the speakers, who was from Fashion Revolution Indonesia members, Winny Nagawaty told that from the previous Fashion Revolution event in Jakarta last year in Senayan City, it was not really effective, because the visitors were just passing through the booth and didn't have concern about it. It didn't create much engagement to their event.

There were also another Fashion Revolution event in December, 20 ${ }^{\text {th }}$ 2017. Another talk show event, which Fashion Revolution Indonesia collaborated with KeKini Coworking Space. Safina Maulida, one of the Fashion Revolution Indonesia member brought the topic was also the same about sustainable fashion education and their mission about Fashion 
Revolution. She stated that not many people concern about sustainable fashion in Indonesia, even including some Fashion Designers, who wasn't care about sustainable fashion and environment cause. It felt weird to bring the eco-fashion topic, which other fashion people think it will against them. According to Imanzah Hidayat, the Country Coordinator of Fashion Revolution Indonesia said, why Fashion Designer can get millions or billions of rupiah, however the tailors were lived under wage. Originally, it came from the fashion school itself. The teacher taught the designer to hire the cheapest tailor and the fashion designer closed their eyes to see the tailor's poverty.

The main problem is about marketing communication, which Fashion Revolution is about social approach to influence human behavior and achieve primary goal for social good, such as environment and humanitarian. Eco-fashion relates to environment, which it won't harm to earth, due to its chemical and waste. Also eco-fashion connects with humanitarian, the poor textile labors' living condition. However, some people are still can't accept the reality.

Based on the background above, there is an importance about clear and constructive plan to make social marketing works. Some of the successful factors to make persuasive social marketing, depends on the people, the message, the media and the audience, which it will be planned in the social marketing effort to make audience concern about eco-fashion. This mindset must be done from the organization itself.

This research can be done from both internalization and externalization standpoints to achieve the insight from another perspective to explore and analyze the problems, especially about eco-fashion marketing communication in social context.

\section{Problem Statement}

Due to the importance of the background, the researcher would like to analyze for this journal about:

"How does the marketing communication implementation by Fashion Revolution Indonesia towards audience concern in Jakarta?"

\section{Study Objectives}

Here are the key objectives, focusing on this journal:

"To analyze, discover the obstacles, and provide suggestions how Fashion Revolution Indonesia can implement their marketing communication for their audience."

\section{LITERATURE REVIEW}

Social marketing is focus on people, wants and needs, aspiration, lifestyle, freedom of choice, and aims for aggregated behavior change of the population or markets. Social 
marketing is useful approach for making solutions of environmental problems by policy planner and campaigners to make global concern to effective action over sustainability issues. However, social marketing can't change immediate behaviors and it is still a key to initiate the social change. Also, there is a high investment of time, financial and human resources for the community, and public will perceive the benefit and promote the wellness to other people (Heck and Yidan, 2013, pp. 50-51).

Many barriers limit the diffusion and sustainability of slow fashion. From macro marketing perspective, there is an opportunity to change with involvement, collective action and investment. Explore the social relations between producers, consumers and collaboration all the actors involved. Appealing to institutional logics, publicizing institutional innovations and allying with powerful institutional actors can be effective in promoting the strength and acceptance of slow fashion (Ertekin and Atik, 2014, pp. 1213).

Guedes (2011) concluded that strategic marketing communication play an essential role in the development of ethical fashion, which the impact on consumers depends both on their access to information and their trust in the information and transparency to influence the consumers to understand the benefits of environment impact (pp. 13-14). Based on communication research by Annika (2015) for slow fashion, she found out that talking about supply chain, consumers did actually concern about working conditions and no chemical are used in the clothes, thinking about their health. Highlighting attributes like quality, durability and suitable with body and style, however price is something important that consumer wanted to know what they are paying for (pp. 50-51).

Sudbury and Boltner (2011) concluded that the young urban consumers criticized fast fashion business practices, however these young consumers do not feel responsible for these practices, blaming governments, retailers, marketers, the media and the levels of development in various countries. The attitudes toward such fashion are positive, but lack of concern over sustainable fashion, means the task of marketing ethical fashion has a steep road ahead and ethical fashion may remain a niche market (p. 167).

Changing one's attitude is quite hard, fast fashion brands are found to make great effort to get more involvement to attract the potential consumer or fans by keeping informed with new items, good look on models and price. Some young people spend considerable time and money for latest style, share their experience and own opinions with others, they are followers. Company uses fashion opinion leaders, word-of-mouth, sending the subscribed email, recently discount, product test or just fashion trend through social circle (Wang, 2010, pp. 43-45). 


\section{Social Marketing}

Social Marketing is also similar with regular commercial marketing, except of focusing selling product to consumers, selling ideas, attitudes and behaviors. To make social marketing strategy works, it relies on 8P's of marketing mix.

1. Product: It is not necessary a physical item. The people must acknowledge the problem and the product is a way to solve the problem.

2. Price: It's important that benefits outweigh the price, or otherwise the new behavior might not be easily adopted.

3. Place: The way the product reaches the consumer. It can be tangible or intangible.

4. Promotion: It ties closely into the place, consisting with advertising, public relations, promotions, and so on.

5. Publics: It refers to the groups. The message must be tailored to the public, based on the needs.

6. Partnership: This is important in social marketing, because the issues are complex and could benefit from collaboration.

7. Policy: Social Marketing campaign aims to change the individual behavior. Important to ensure the changes are sustainable through supporting policies.

8. Purse Strings: Identify the source of funds to initiate and sustain, helps to increase the success of campaign (NASCA Conservation, 2017, pp. 1-2).

\section{Persuasive Communication}

According to Perloff (1993), there are some persuasive strategies, which can be used in a campaign. Those include:

1. Campaigner / Communicator: The person, who initiate, design, organize and send the message in the campaign activity is called campaigner. Need to have trusted communicator to deliver the message.

2. Campaign Message: Campaign is a message delivery from sender to receiver through several media to create audience intention and response.

3. Campaign Media: Media is a figure or path to deliver the message.

4. Campaign Target Audience / Communicant: Target audience who most of the knowledge, attitude and behavior will be change by campaign activity.

Hogan (1996) described 9 common principles of persuasion in campaign activity. Such as:

1. The principle of reciprocity: If someone accepts something valuable, they will respond and also willing to give something.

2. The principle of contrast: People tend to memorize things in the past experience or have been told that the things are better than before.

3. The principle of friendship: If the communicators position themselves as friends from particular group, possibly individuals or groups will accept them.

4. The principle of hope: People tend to do something, which they have a hope to someone they believe and respect. 
5. The principle of association: People tend to like a product, services or idea, which supported by someone they like or respect.

6. The principle of consistency: Communicator has to bring up the added value from certain action. Indirectly speaking that people's statement may be changed.

7. The principle of scarcity: If something is increasingly rare, the value will be bigger. People tend to do something, if they won't get the same chance at the other place or time.

8. The principle of compromise: Most people will tend to agree with suggestion, product, service, which will be looked and accepted by majority of people or group.

9. The principle of authority: The more powerful of person to be perceived by others, the bigger chance the request will be considered and accepted.

\section{Diffusion of Innovation}

Based on Robinson (2009), there are five attributes that indicate people's perspective:

1. Relative advantages: A degree that an innovation is perceived as better than the idea it supersedes by particular group of users. The greater they perceived, the more rapid of the adoption.

2. Compatibility: A degree that an innovation is perceived as being consistent with values, past experiences and needs of potential adopters. If the idea is incompatible, it won't be adopted.

3. Complexity: A degree that an innovation is perceived as difficult to understand. If the new ideas are simpler to understand, it will rapidly adopted than innovations which require new skills and understandings.

4. Triability: A degree that an innovation can be experimented with a limited basis. If the innovation is trialable, less uncertainty to person who is considering about it.

5. Observability: if the individuals can see the result of the innovation, they are more likely to adopt it. It creates lower uncertainty and make stimulation to peer discussion of new idea (p. 2).

A population can be broken down into five segments to adopt an innovation:

1. Innovators: This segment begins with a tiny number of visionary, imaginative innovators. They have great time, energy and creativity to create new ideas. However, it can make them dangerously idealistic to the pragmatic majority.

2. Early Adopters: This segment begins when once the benefits start to become apparent, they look out for strategic leap in ther lives or businesses, make a connection between innovations and personal needs.

3. Early Majority: This segment is mass audiences. They are pragmatists, comfortable with moderately progressive ideas, but they won't act without proof of benefits. They are followers and influenced by mainstreams, want to hear as industry standard and endorsed by normal, respectable folks. 
4. Late Majority: This segment is conservative pragmatists who hate the risk and unconfortable with new idea.They are only follow mainstreams and established standards. Influenced by fears and laggard opinions.

5. Laggards: This segment is the people who see the high risk in adopting a particular product or behavior. They are worried and thinking to bring the argument against it. They can be an innovators, but challenge the paradigms (Robinson, 2009, pp. 58).

\section{METHOD}

From research methods, the writer will use qualitative approach. The qualitative is used to understand the phenomenon about subject research. It could be about attitude, perception, action, and so on, holistically and with how to describe into the words and language from the certain context, naturally and use many natural methods (Moleong, 2006, p. 7). The qualitative orientation is chosen by researcher, due to curiosity about the data, the researcher uses Semi-Structured Interview, which the researcher uses interview guidance, as a specific form of instruction to direct the researcher to implementation of marketing communication by Fashion Revolution Indonesia in Jakarta from November 2017 until April 2018 to communicate the message about the reality, exploring the insight about eco-fashion, which includes words, feelings and reaction rather than quantitative method where statistical numbers are of interest (Bryman and Bell, 2015).

\section{Data Collection Methods}

For the primary do an interview (Kriyantono, 2009, pp. 96-100). Also for observation approaches, the researcher's method will be used are semi-structured and nonparticipant approaches. The researcher doesn't become, nor aims to become a part of system or community, which they are observing (non-participant), and uses some manner of observation schedule or checklist to organize observations. However can attempt to observe and record the unplanned or unexpected (semi-structured) (O'Leary, 2009, pp. 4-6).

For the secondary data, The researcher can use it, which can be found in the journal, books, blog, articles, news or supporting data to fit up the other primary data (Kriyantono, 2009, p. 42).

\section{Research Limitation}

The field research is only done in Jakarta area for Fashion Revolution marketing communication activity from November 2017 until April 2018 (six month period). Other greater than Jakarta, the researcher can find it from Internet, books, journal, articles or secondary data with legitimate sources to collect the data and comparison as to find the answer, based on problem statement. 


\section{RESULTS AND DISCUSSION}

For the observation and interview result, the researcher was focused on 2017 campaign (6 month) period. The focus research is regarding to marketing communication.

\section{Fashion Revolution x Senayan City}

Started from November, $11^{\text {th }}$ 2017, the researcher has come to Fashion Revolution event, which it was a talk show event, collaborated with Pasar Semesta, which brought the topic about Sustainable Fashion talk and the room was around 40 persons and most of the audiences are eco-concern. There were five speakers involved, Fashion Revolution, Osem, Sukkhacitta, The Aid Kit and Kurnia Ratu Kencana. This event, the speakers were giving the education about the behind the scene of fast fashion and introduction of sustainable fashion. Fashion Revolution Indonesia told their audience who aware about fashion industry about their mission. One of the speakers, who was from Fashion Revolution Indonesia members, Winny Nagawaty told that from the previous Fashion Revolution event in Jakarta last year in Senayan City, it was not really effective, because the visitors were just passing through the booth and didn't have concern about it. It didn't create much engagement to their event.

The researcher backed track, how Fashion Revolution Indonesia implement their event in the past. For media selection, they activate two channels, digital and event marketing to spread awareness. Fashion Revolution Indonesia doesn't have their own website or official Facebook, but they have Instagram (@fash_revid) and Twitter (@Fash_RevID). The organizer is started to activate their social media, 2 weeks before the first initial event on Senayan City. Firstly, the content is from the global to be used in Indonesian content. The picture of the post is about quote and picture about eco-fashion. There was some information about Fashion Revolution Week, including the date. Unfortunately, there is no information about the place, where they initiate their event. Until the D-Day, they put the information where is the event. All the contents are organic, so the engagement is very low for the first run. The recommendation for this is to understand about how to make digital content plan. The target audience must aware about the place, time and date before the event was initiated. Because the social media was just started, they need people, who have strong connection to endorse the account, and let them drive people to visit the Fashion Revolution Indonesia account.

Talking about the event itself. It is actually a booth display as engagement area for photobooth, collaboration with Senayan City and British Council. There were bunches of card with message to support eco-fashion and the insight where our clothes are made. However, that booth is no call to action to spread the word by taking pictures and lack of activity. If we connect to creative marketing element, the good marketing should be made audience concern, curious or surprise element in it. In this case, the booth display had to be a signal for audience to do action for spreading the word. Creative visual of fashion elements need to be emphasized. As for the place itself in the mall, it is a great place as in 
Senayan City. But, the high fashion boutiques are domineering on the surrounding, and there were no single eco-fashion clothes in the booth. The result, booth itself is not powerful to engage the audience.

\section{Fashion Revolution x Pasar Semesta}

Back to the talk show event with Pasar Semesta. In this event, the researcher came for observation in the field. About 40 people came to the event and it was full booked. Based on the researcher's finding, Pasar Semesta has good digital account to spread awareness. However, Fashion Revolution Indonesia didn't maintain Instagram anymore. The exposure didn't come from Fashion Revolution and it came from their collaborator, Pasar Semesta. Fashion Revolution Indonesia was lack of marketing and it depends on their collaborator. From the post itself, there are five speakers, Osem, Organic Cotton, Sukkhacitta, and The Aid Kit.

This post created interest to people who concern about social environment.

Some key points which researcher can conclude. The engagement was high, because of the post. The visual is specific for eco-fashion and there were five speakers. However, in this event, Pasar Semesta was the organizer and Fashion Revolution was the speaker. The persuasive element that communicator who had credibility was explicitly announced, clear message about the topic, strong media presence with followers who the target audience was concern about social activities and eco-fashion. Also in persuasive, the principle of association that the audience felt relevant with the product and the principle of authority was used for speaker backgrounds and event sponsorship from some well known brand like WWF, DBS and Thamrin School to increase the credibility.

In this event, the researcher interviewed Winny Nagawaty, the Fashion Revolution campaigner. She said that if we want to make people know about eco-fashion, it should make eco-fashion as a trend. The researcher analyzed this statement. To make a trend, it is very important for marketing communication in the right channels like using influencer or word of mouth marketing. Trend will spread if the target audience will feel relevant with the context and share the content, whether it is online or offline. However, the downside of this statement, trend is tended to be fad. It will disappear with people don't maintain the topic existence. There is the difference between social marketing and commercial marketing. The approach of commercial marketing is easier to create hype, because it is based on what people's need and wants. In fashion realm, people will have a pride if they can own the clothes. In contrast, social marketing is focus on changing behavior, which to control the addictive attitude. My suggestion, if we want to create hype about eco-fashion, we need to emphasize added value of eco-fashion. Showing what is the competitive advantage between eco-fashion and fast fashion. Sense of emotional persuasive approach with the principle of hope, contrast, friendship and consistency, people will concern about eco-fashion and have a sense of satisfaction to learn more about eco-fashion. 


\section{Fashion Revolution x Kekini Coworking Space}

Another Fashion Revolution activity in December, 20 ${ }^{\text {th }}$ 2017. The researcher came to another talk show event, which Fashion Revolution Indonesia collaborated with KeKini Coworking Space. In that room, only a half of the room was filled with 15 persons and only Fashion Revolution Indonesia was the speaker. Safina Maulida, one of the Fashion Revolution Indonesia member brought the topic was also the same about sustainable fashion. Based on researcher observation, the audience was less than previous event, which it is around 40 people. Unfortunately, Fashion Revolution Indonesia instagram account was still not active. For the activity post, it came from KeKini Coworking Space digital account. If the audience saw the post, they could the topic, place, and name of the speaker.

The researcher had interviewed Safina. The objective of Fashion Revolution campaign is to make people concern, who made their clothes which they worn, especially for millennial. The plan is to make viral and massive awareness from social media. If we compare from previous campaign from Pasar Semesta, the followers of Kekini is less than Pasar Semesta. The types of followers and engagement in social media influenced how many people to be attracted by eco-fashion. Another factor is Fashion Revolution Indonesia speaker, thinking about Fashion Indonesia awareness and credibility of the organization.

Safina stated that not many people concern about sustainable fashion in Indonesia, even including some Fashion Designers, who wasn't care about sustainable fashion and environment cause. It felt weird to bring the eco-fashion topic, which other fashion people think it will against them. From this experience, we can correlate to innovation of diffusion theory. People who reject the idea means they are pragmatists, comfortable with moderately progressive ideas, but they won't act without proof of benefits. They are followers and influenced by mainstreams, want to hear as industry standard and endorsed by normal, respectable folks. Eco-fashion should be given the added value, comparing with fast fashion. As eco-fashion is more expensive rather than fast fashion. Fashion Revolution Indonesia is trying to aim millenial, would be an easier penetration. Also based on innovation of diffusion, millenials are early adopters. They are easier to receive the innovation and open minded to the social change. If the community was built, the early majority and late majority will follow.

\section{Fashion Revolution x British Council}

On 15 th April 2018, the researcher came back to observe the campaign. Fashion Revolution had collaboration with British Council. The scenario is the same as Pasar Semesta. Five speakers came including Wilsen Willim as Fashion Designer, Parang Kencana, Fashion Revolution, British Council and Burgreens. Around 80 people came to that event. It had connection that more credible speakers, more audience came to their event, and the post had been blasted by British Council account, which they have a $9 \mathrm{~K}$ followers. 


\section{Fashion Revolution x Greener.E}

The last researcher's observation, on April 22 nd, 2018 , Fashion Revolution had collaboration with Jakartagreener.e in Sunday Market. When the researcher joined the event, only less than 10 people came. If we see the Sunday Market background, it is an event to sell green products. Fashion Revolution was the speaker and there are only one speaker, Imanzah Nurhidayat. The media exposure only came from Jakarta Greener.E, however at the talkshow, Fashion Revolution was a solo talkshow. From all correlation with lack of audience, is because lack of marketing communication effort from Fashion Revolution itself.

The researcher had interview with Safina and Imanzah, they concluded that the organization is voluntary and initiative. Imanzah role as Country Coordinator and Safina as Campaigner. As the researcher asked their activity, Safina said that they are rarely come together to the internal meeting. Fashion Revolution also highlighted that they don't have any budget to initiate the marketing communication. The small thing that they can do is from digital presence.

Based on this interview, it concluded that to initiate marketing communication, it is about the internal organization itself, correlated with marketing mix, there is partnership point. Fashion Revolution needs to do partnership with other bodies, volunteers and community. Due to reach the goal for massive impact, it is difficult if it is just using social media and event. They have to treat it like a business. Fashion Revolution Global has fundraising program to initiate their mission. It's all stated from the campaigner itself.

\section{CONCLUSION}

From all qualitative research with interview and observation, the key is about sustainability. It means that to make the mission work, Fashion Revolution Indonesia has to treat this as a business. Specifically for marketing mix from both internal and external factors influences the attitude change of the target audience.

To strengthen the awareness, it comes from people, who are already concern about ecofashion. If the community is strong, they will spread the message about eco-fashion. In the innovation of diffusion, the early and late majority later will follow.

Also, to achieve the Fashion Revolution campaign objective is to make people curious who made our clothes, use persuasive communication. The credibility of organizer, relevancy and using media to spread the word are influence people to lead attitude change. 


\section{REFERENCES}

Annika, K. (2015). Communication of Sustainable Fashion: To Communicate Sustainable Fashion Through The Label. Sweden: The Swedish School of Textiles, pp. 50-51.

Bianchi, C. and Birtwistle, G. (2011). Consumer Clothing Disposal Behavior: A Comparative Study. International Journal of Consumer Studies. New Jersey: Blackwell Publishing, Ltd., pp. 335-341.

Bryman, A. and Bell, E. (2015). Business Research Methods. Oxford University Press.

Ertekin, Z.O. and Atik, D. (2014). Sustainable Markets: Motivating Factors, Barriers, and Remedies for Mobilization of Slow Fashion. London: Sage Publishing, pp. 12-13.

Fletcher, K. (2007). “Slow Fashion.” Retrieved June 1, 2007, from https://theecologist.org/2007/jun/01/slow-fashion

Fletcher, K. (2010). Slow Fashion: An Invitation for Systems Change. Fashion Practice: The Journal of Design, Creative Process \& Fashion. pp. 259-266.

Guedes, M.G. (2011). Ethical Fashion Brands: Promotion Approach or a Real Value? Portugal: Universidade do Minho, pp. 13-14.

Heck G. and Yidan X. (2013). The Effects of Sustainable Marketing on Brand Equity and Consumer Behavior. Sweden: Halmstad, pp. 50-51.

Henninger, C.E., Alevizou, P., Goworek, H., and Ryding, D. (Eds.). (2017). Sustainability in Fashion: A Cradle to Upcycle Approach. Basingstoke: Palgrave Macmillan Ltd., p.70.

Hogan, K. (1996). The Psychology of Persuasion: How to Persuade Others to Your Way of Thinking. Louisiana: Pelican Publishing.

Idacavage, S. (2016). “Fashion History Lesson: The Origins of Fast Fashion.” Retrieved June 8, 2016, from https://fashionista.com/2016/06/what-is-fast-fashion

Kriyantono, R. (2009). Teknik Praktis Riset dan Komunikasi: Disertai Contoh Praktis Riset Media, Public Relations, Advertising, Komunikasi Organisasi, Komunikasi Penasaran. Jakarta: Kencana.

Made By Organization. (2013). Environmental Benchmark for Fibres. California: Brown \& Wilmanns Environmental, LLC, p. 6.

Moleong, L.J. (Eds.). (2010). Metodologi Penelitian Kualitatif: Edisi Revisi. Bandung: Remaja Rosdakarya.

Motlagh, J. (2016). “Rana Plaza, Three Years Later: Who Has Paid?”. Retrieved September 7, 2016, from https://www.aljazeera.com/indepth/features/2016/09/rana-plaza-years-paid160906085006302.html 
Moon, KK-L., Youn, C., Chang J.M.T., \& Yeung, AW-h. (2013). "Product Design Scenarios for Energy Saving: A Case Study of Fashion Apparel", International Journal of Production Economics, vol. 146, no. 2, pp. 392-401.

Museum Fur Kunst Und Gewerbe. (2017). Fast Fashion. Hamburg : Author

Niinimaki, K. (2013). Sustainable Fashion: New Approaches. Helsinki: Aalto University, p. 35.

O’Leary, Z. (2014). The Essential Guide to Doing Your Research Project. $2^{\text {nd }}$ Edition. London: Sage Publishing.

Perloff, R. M. (2003). The Dynamics of Persuasion: Communication and Attitudes in the 21 Century. $2^{\text {nd }}$ Edition. New Jersey: Lawrence Erlbaum.

Robinson, L. (2009). Changeology. Cambridge: UIT Cambridge Ltd.

Rohwedder, C. (2004). "Making Fashion Faster". Retrieved February 24, 2004, from https://www.wsj.com/articles/SB107758500479837295

Rubya, T. (2014). “The Ready-Made Garment Industry: An Analysis of Bangladesh's Labor Law Provisions After the Savar Tragedy", Brooklyn Journal of International Law, pp. 685-718.

Smithers, R. (2013). "Benetton Admits Link with Firm in Collapsed Bangladesh Building”. Retrieved April 29, 2013 from https://www.theguardian.com/world/2013/apr/29/benetton-link-collapsedbuilding-bangladesh

Sudbury, L. and Boltner, S. (2011). Fashion Marketing and the Ethical Movement Versus Individualist Consumption: Analyzing the Attitude Behaviour Gap. Minnesota: Association for Consumer Research, p. 167.

Tokalti, N. \& Kizilgun, O. (2008). "From Manufacturing Garments for Ready-To-Wear to Designing Collections for Fast Fashion Evidence from Turkey". Environment and Planning A, vol. 41, no. 1, pp. 146-162.

Wang, T.Y. (2010). Consumer Behaviour Characteristics in Fast Fashion. Sweden: Textilhogskolan, pp. 43-45.

Yardley, J. (2013). “Report on Deadly Factory Collapse in Bangladesh Finds Widespread Blame". Retrieved May 22, 2013, from https://www.nytimes.com/2013/05/23/world/asia/report-on-bangladeshbuilding-collapse-finds-widespread-blame.html 